\title{
Myricetin inhibits angiotensin converting enzyme and induces nitric oxide production in HUVEC cell line
}

\author{
Mehmet Berköz ${ }^{1}$, Metin Yıldırım², Serap Yalın², Mert İlhan ${ }^{3}$ and Oruç Yunusoğlu ${ }^{4}$ \\ ${ }^{1}$ Department of Biochemistry, Faculty of Pharmacy, Van Yuzuncu Yil University, Van, Turkey \\ ${ }^{2}$ Department of Biochemistry, Faculty of Pharmacy, Mersin University, Mersin, Turkey \\ ${ }^{3}$ Department of Pharmacognosy, Faculty of Pharmacy, Van Yuzuncu Yil University, Van, Turkey \\ ${ }^{4}$ Department of Medical Pharmacology, Faculty of Medicine, Van Yuzuncu Yil University, Van, Turkey
}

\begin{abstract}
Nitric oxide is known as relaxing factor because it acts as a vasodilator, increases blood flow, and inhibits platelet aggregation and adhesion, on the other hand nitric oxide can modulate cellular and physiological processes to limit oxidative injury, limiting processes such as leukocyte adhesion. As the complete mechanism of myricetin and its cardiovascular benefits is not completely understood, the aim of this study was to investigate the antihypertensive activity of myricetin in human umbilical vein endothelial cell (HUVEC). Angiotensin converting enzyme (ACE) activity, nitric oxide production, reactive oxygen species (ROS) scavenger activity, cellular calcium concentration, and endothelial nitric oxide synthase (eNOS) activity and protein expression was investigated in HUVEC treated with different concentration of myricetin (1-60 $\mu \mathrm{M})$. Myricetin increased nitric oxide production in HUVEC through decreased ROS levels and increased nitric oxide production and eNOS activation. Activation of eNOS enzyme was achieved by an increase of cellular calcium concentration. At the same examined concentration of myricetin, the activity of ACE was significantly inhibited. These findings indicate that myricetin may be helpful for lowering blood pressure; this could be achieved through dietary intervention or by the production of new antihypertensive treatments from a natural product.
\end{abstract}

Key words: Angiotensin converting enzyme - Antihypertensive activity — Endothelial nitric oxide synthase - HUVEC cell line - Myricetin

Abbreviations: ACE, angiotensin converting enzyme; eNOS, endothelial nitric oxide synthase; HUVEC, human umbilical vein endothelial cell; MTT, 3-(4,5-dimethylthiazol-2-yl)-2,5-diphenyltetrazolium bromide; ROS, reactive oxygen species.

\section{Introduction}

High blood pressure is a major risk factor for some chronic diseases such as stroke, renal disease, and cardiovascular disease (Mittal and Singh 2010). In patients with hypertension, angiotensin II is produced from angiotensin I by the catalytic effect of angiotensin converting enzyme (ACE) in higher amounts than normal (Fuchs et al. 2008; Gowrisankar and

Correspondence to: Mehmet Berköz, Department of Biochemistry, Faculty of Pharmacy, Van Yuzuncu Yil University, Zeve Campus, 65080 Van, Turkey

E-mail: mehmet_berkoz@yahoo.com
Clark 2016). Angiotensin II acts as vasoconstrictor, increasing blood pressure. For this reason, inhibition of ACE activity is a pharmacological target for the treatment of hypertension (Li et al. 2017). The ACE enzyme has a $\mathrm{Zn}^{2+}$ ion in its two active sites (Wang et al. 2011). Substrate binding and catalysis of ACE indicate the mechanism of $\mathrm{Zn}^{2+}$ ion (Bernstein et al. 2018). One of the mechanisms of ACE inhibitors is the ability to bind the $\mathrm{Zn}^{2+}$ ion (Braun and Rosenfeldt 2013). High and unregulated production of reactive oxygen species (ROS) is another risk factor for heart disease (Dong et al. 2019; Nanayakkara et al. 2019). In endothelial cells, enzyme systems involving NADPH oxidase, xanthine oxidase, and the mitochondrial respiratory chain are responsible for ROS 
production (Burtenshaw et al. 2017). ROS production should be regulated or adverse effects like oxidation will be cause to cell macronutrients such as proteins, lipids, and nucleic acids. Balance in ROS concentration can be achieved by the antioxidant system that exists in the human body and by antioxidant supplement (Bolisetty and Jaimes 2013). Moreover, ROS have the ability to oxidize nitric oxide produced from endothelial cells, leading to endothelial dysfunction and the initiation and development of cardiac disease (CervantesGracia et al. 2017; Khaddaj et al. 2017).

Nitric oxide is known as relaxing factor because it acts as a vasodilator, increases blood flow, and inhibits platelet aggregation and adhesion. On the other hand, nitric oxide can also abate the oxidation chemistry mediated by reactive oxygen species such as $\mathrm{H}_{2} \mathrm{O}_{2}$ and $\mathrm{O}^{2-}$ that occurs at physiological levels of nitric oxide. In addition to the antioxidant chemistry, nitric oxide protects against cell death mediated by hydrogen peroxide, alkylhydroperoxides, and xanthine oxidase. The attenuation of metal/peroxide oxidative chemistry, as well as lipid peroxidation, appears to be the major chemical mechanisms by which nitric oxide may limit oxidative injury to mammalian cells. In addition to these chemical and biochemical properties, nitric oxide can modulate cellular and physiological processes to limit oxidative injury, limiting processes such as leukocyte adhesion (Maiuolo et al. 2019). Calcium-dependent endothelial nitric oxide synthase (eNOS) is one of the important factors responsible for the production of nitric oxide in endothelial cells. Increased levels of nitric oxide in the endothelial cells are often due to the increased protein expression of the eNOS enzyme or by scavenging the ROS produced within the cells (Shu et al. 2015).

Several research groups have reported a significant interaction between biological systems and dietary polyphenols from vegetables and fruits. Six flavonoids namely apigenin, luteolin, kaempferol-3-O- $\alpha$-arabinopyranoside, kaempferol-3-O- $\beta$-galactopyranoside, quercetin-3-O- $\alpha$ arabinopyranoside and luteolin-7-O- $\beta$-glucopyranoside were isolated from Ailanthus excelsa (Roxb) in a study conducted by Loizzo et al. (2007). The ACE inhibition activities<smiles>O=c1c(O)c(-c2cc(O)c(O)c(O)c2)oc2cc(O)cc(O)c12</smiles>

Figure 1. Chemical formula of myricetin. of those flavonoids were tested. According to the results, all flavonoids displayed ACE inhibitory activity but the most active flavonoid was kaempferol-3-O- $\beta$-galactopyranoside with an $\mathrm{IC}_{50}$ value of $260 \mu \mathrm{M}$. Furthermore, Balasuriya and Rupasinghe (2011) reported that quercetin, quercetin3-glucoside, quercetin-3-galactoside, cyanidin-3-galactoside showed ACE inhibitor activity with the $\mathrm{IC}_{50}$ values of 151 $\mu \mathrm{M}, 71 \mu \mathrm{M}, 180 \mu \mathrm{M}, 206 \mu \mathrm{M}$, respectively.

Myricetin (3,3',4'5,5',7-hexahydroxylflavone) is a common natural flavonoid found in many fruits, vegetables, and herbs (Fig. 1). Myricetin plays a substantial role in the treatment and prevention of some diseases due to its potent iron-chelating capability, antioxidant and free-radical scavenging activities (Yao et al. 2014). It has been also used to treat inflammatory diseases and hypotensive with a variety of pharmacological functions such as anti-inflammatory, analgesic, anti-tumor activities and protecting liver, showing a high potential value for therapeutic application. In addition, recent researches indicated that myricetin can significantly depress the level of pro-inflammatory cytokines such as interleukin-1 $\beta$ (IL-1 $\beta$ ) and tumor necrosis factor- $\alpha$ (TNF- $\alpha$ ) by down regulating the activation of the Akt, mTOR and NF- $\kappa$ B pathways, alleviating inflammation reaction to offer protective effect on various organs (Lee da and Lee 2016).

As the complete mechanism of myricetin and its cardiovascular benefits is not completely understood, the aim of this study was to investigate the effect of myricetin on ACE activity, nitric oxide production, ROS scavenger activity, cellular calcium concentration, and eNOS protein expression in human umbilical vein endothelial cell (HUVEC).

\section{Materials and Methods}

\section{Materials}

HUVEC cell line was purchased from American Type Culture Collection (ATCC ${ }^{\circledR}$ PCS-100-010). Myricetin was commercially obtained from Sigma-Aldrich, USA (Catalog No: M6760). All cell culture chemicals were bought either from Sigma-Aldrich or Merck. Antibody eNOS and $\beta$-actin mouse $\mathrm{mAb}$ were purchased from Santa Cruz Biotechnology (Santa Cruz, CA, USA). All the other chemicals were bought either from Sigma-Aldrich, Merck or other standard suppliers.

\section{Cell culture}

The cells were seeded in DMEM with high glucose content ( $4.5 \mathrm{~g} / \mathrm{l})$, and supplemented with $10 \% \mathrm{FBS}$ and $5 \%$ penicillin. Different myricetin concentrations $(1-100 \mu \mathrm{M})$ were tested on HUVEC cells to measure the cell viability and nitric oxide 
production. Briefly, a stock solution of myricetin $(10 \mathrm{mM})$ was prepared in DMSO. HUVEC cells were seeded into 96 well tissue culture plates at a density of $1 \times 10^{4}$ cells $/ 200 \mu \mathrm{l}$ DMEM serum media. Once the cells reached $60-70 \%$ confluence, they were treated with myricetin for 12,24 , or $48 \mathrm{~h}$ (Do et al. 2015).

\section{Nitric oxide assay}

Nitric oxide levels in the cell supernatant were measured by Griess kit, at each experimental time (12,24, or $48 \mathrm{~h}$ ) in all groups. According to the Griess kit instructions, $100 \mu \mathrm{l}$ of medium supernatant was mixed with $100 \mu \mathrm{l}$ Griess reagent $(0.1 \% \mathrm{~N}$-naphthylethylethylenediamine dihydrochloride in $5 \%$ phosphoric acid and $1 \%$ sulfanilamide, mixed in a $1: 1$ ratio). The formation of a yellow colour was measured at 550 $\mathrm{nm}$ using a VersaMax Microplate Reader; the colour intensity was proportional to nitrite concentration. A sodium nitrite standard curve was obtained using a sodium nitrite standard solution supplied with the kit (Bredt et al. 1994).

\section{Cell viability assay}

Cell viability was measured by 3-(4,5-dimethylthiazol2-yl)-2,5-diphenyltetrazolium bromide (MTT) assay, at each experimental time $(12,24$, or 48 hours). Cells pretreated with different concentrations of myricetin were incubated with $20 \mu \mathrm{l}$ of MTT dye ( $5 \mathrm{mg} / \mathrm{ml} \mathrm{PBS}$ ) at $37^{\circ} \mathrm{C}$ and $5 \% \mathrm{CO}_{2}$ to measure cell viability after different incubation times. At the end of each experimental time, the culture medium was aspirated and $100 \mu \mathrm{l}$ of DMSO was added to each well. The formazan crystals produced were dissolved completely by shaking the plate for $30 \mathrm{~s}$ at room temperature. The purple colour produced was measured at $492 \mathrm{~nm}$ using a VersaMax Microplate Reader (Mosmann 1983).

\section{ACE activity assay}

As a result of a meaningful reduction in cell viability after incubation for $48 \mathrm{~h}, 24 \mathrm{~h}$ incubation was performed in the following stages of the current study. Angiotensin converting enzyme activity was measured in the HUVEC cell line after $24 \mathrm{~h}$ of exposure to different concentrations of myricetin ( 1 , $20,40$ and $60 \mu \mathrm{M})$ using a modified fluorometric method (Kapiloff et al. 1984). Briefly, HUVEC cells were seeded to confluence in $25 \mathrm{~cm}^{2}$ flasks $\left(1 \times 10^{6}\right.$ cells/ml) and then incubated with myricetin $(1,20,40$ and $60 \mu \mathrm{M})$ for $24 \mathrm{~h}$. Treated cells were washed three times with $3 \mathrm{ml}$ Hank's Balanced Salt Solution (HBSS) buffer. The cells were scraped from the flask with $1 \mathrm{ml} \mathrm{HBSS}$ and frozen at $-20^{\circ} \mathrm{C}$ until assayed. For the assay, frozen cells were thawed and sonicated then $20 \mu \mathrm{l}$ samples were added to $80 \mu \mathrm{l}$ of $\mathrm{H}-\mathrm{H}-\mathrm{L}$ ( $5 \mathrm{mM}$ prepared in HBSS buffer) and incubated at $37^{\circ} \mathrm{C}$ for $3 \mathrm{~h}$. The incubated cells were then mixed with $1.4 \mathrm{ml} \mathrm{NaOH}(0.5 \mathrm{~N})$ to stop the reaction. The fluorescent dye, o-phthaldialdehyde $(100 \mu \mathrm{l}$ of $10 \mathrm{mg} / \mathrm{ml}$ in methanol) was used to detect the histidylleucine reaction product. The reagents were incubated for $5 \mathrm{~min}$ at room temperature followed by the addition of $250 \mu \mathrm{l}$ of HCI (6 N). A spectrofluorimeter (Hitachi F-7000, Berkshire, U.K.) was used to measure the fluorescence of the samples using an excitation wavelength of $365 \mathrm{~nm}$ and an emission wavelength of $495 \mathrm{~nm}$. Fluorescence intensity is directly proportional to ACE activity, whereas it is inversely proportional to ACE inhibition. ACE activity was expressed as $\mathrm{pg} / \mathrm{ml}$, and the percentage of ACE inhibition was calculated. Captopril $(1 \mu \mathrm{M})$ was used as positive control in place of myricetin (Kapiloff et al. 1984).

\section{Measurement of ROS}

Dichlorofluorescein dye (non-fluorescent CM- $\mathrm{H}_{2}$ DCFDA) has the ability to diffuse through the cell membrane. In the cytoplasm, this dye is hydrolysed enzymatically by intracellular esterases and rapidly converted to fluorescent dye (DCF) in the presence of ROS. The fluorescence intensity is proportional to the ROS content (Osseni et al. 1999). The ROS level in the HUVEC cell line was determined by flow cytometry, using $\mathrm{CM}-\mathrm{H}_{2}$ DCFDA dye after incubation with $1,20,40$, and $60 \mu \mathrm{M}$ myricetin. HUVEC cells were seeded in $25 \mathrm{~cm}^{2}$ flasks at $1 \times 10^{6}$ cells $/ \mathrm{ml}$. The treatments were added when cells reached the desired cell confluence $(60-70 \%)$. After 24-h incubation time, half of pre-treated cells were exposed to $10 \mathrm{nM}$ angiotensin II for $1 \mathrm{~h}$, while the other left untreated. The cells were trypsinised and centrifuged for $3 \mathrm{~min}$ at $150 \times g$. The supematant was removed, the pellets washed with $2 \mathrm{ml}$ of HBSS buffer and centrifuged. The supematant was discarded and the cells re-suspended in $1 \mathrm{ml}$ HBSS. Re-suspended cells were then incubated with $5 \mu \mathrm{M}$ CM- $\mathrm{H}_{2}$ DCFDA (prepared in DMSO) for $30 \mathrm{~min}$ at $37^{\circ} \mathrm{C}$ and $5 \% \mathrm{CO}_{2}$. At the end of the incubation time, cells were kept on ice under low light conditions due to the high susceptibility of the dye to photo-oxidation. Dichlorofluorescein florescence was then measured using a flow cytometer (FACSCalibur, Becton Dickinson, USA). At least 10,000 events were acquired in the gated regions at $488 \mathrm{~nm}$ excitation and 532 emission (Osseni et al. 1999).

\section{Determination of cellular calcium concentration}

Intracellular calcium concentrations were measured by fluorometry after loading the cells with fura-2/AM dye. Free intracellular calcium will bind with the membrane diffusible fluorescent dye fura-2/AM (Grynkiewicz et al. 1985). Briefly, HUVEC cells were cultured in $25 \mathrm{~cm}^{2}$ flasks at $1 \times 10^{6}$ cells/ $\mathrm{ml}$ concentration. Different concentrations of myricetin (1, 20,40 and $60 \mu \mathrm{M}$ ) were incubated with the cells after they 
reached $60-70 \%$ confluence. Following 24-h incubation, cells were loaded with $5 \mu \mathrm{M}$ fura-2/AM dye and incubated for $45 \mathrm{~min}$ at $37^{\circ} \mathrm{C}$ and $5 \% \mathrm{CO}_{2}$. Consequently, the dye was removed and the cells were washed and scraped from the flask with $2 \mathrm{ml}$ HBSS buffer. The calcium concentration was detected by spectrofluorimetry (Hitachi F-7000, Berkshire, U.K.) with excitation and emission wavelengths of $340 \mathrm{~nm}$ and $510 \mathrm{~nm}$, respectively. Intracellular calcium concentration was expressed as nM. Ethyleneglycoltetraacetic acid (EGTA) at $1 \mathrm{mM}$ was used as negative control instead of myricetin (Grynkiewicz et al. 1985).

\section{eNOS activity assay}

Cells treated with different concentrations of myricetin (1, 20,40 and $60 \mu \mathrm{M}$ ) for $24 \mathrm{~h}$ were lysed, and frozen at $-20^{\circ} \mathrm{C}$ until eNOS activity was measured. $1 \mathrm{mM}$ EGTA was used as a negative control in place of myricetin. eNOS activity was measured using a nitric oxide synthase assay colorimetric kit (Bioassay System, Hayward, CA, USA) (Catalog No: ENOS-100) using a direct and non-radioactive method. According to the manufacturer's instructions, this kit is designed to measure eNOS activity in two steps. The first step is an oxidation reaction by an eNOS enzyme that oxidises the amino acid arginine to nitric oxide. The second step is detection of nitric oxide via a reduction reaction. Nitric oxide is rapidly oxidised to nitrite and nitrate after production, thus the reduction of nitrate to nitrite by Griess method was used to measure nitric oxide production. The yellow colour produced was measured at $540 \mathrm{~nm}$ using a VersaMax Microplate Reader. A nitric oxide synthase standard curve was obtained using a eNOS standard solution supplied with the kit.

\section{eNOS protein expression assay by Western blot}

HUVEC cells at a density of $1 \times 10^{6}$ cells/ml were seeded in $25 \mathrm{~cm}^{2}$ tissue culture flasks. Once $50 \%$ confluence was achieved, cells were treated with 1, 20, 40 and $60 \mu \mathrm{M}$ myricetin and incubated for $24 \mathrm{~h}$. After this incubation, the culture media was decanted and cells were washed with $5 \mathrm{ml}$ PBS. The cells were then trypsinized and the resulting cell suspension centrifuged at $1500 \times g$ for 3 min with $5 \mathrm{ml}$ PBS to wash. Supernatants were removed and the cell pellets were lysed by adding $300 \mu \mathrm{l}$ of lysis buffer. The last step for cell lysis was to keep the cells on ice for $20 \mathrm{~min}$ and then store them at $-80^{\circ} \mathrm{C}$ until protein determination and Western blot experiment were carried out. Total protein concentrations of the supernatant were determined by Pierce ${ }^{\mathrm{Tn}}$ BCA Protein Assay Kit (Thermo Scientific Pierce).

An equal amount of total protein $(20-50 \mu \mathrm{g})$ was loaded into sodium dodecyl sulphate-polyacrylamide gel electrophoresis and separated by electrophoresis under 80-100 V.
After electrophoresis, the protein bands were transferred to polyvinylidene difluoride (PVDF) membrane under $100 \mathrm{~V}$ for $1 \mathrm{~h}$ in cold water bath. Then, the PVDF membranes were blocked with phosphate-buffered saline (PBS) containing 5\% nonfat milk or BSA for $1 \mathrm{~h}$ and incubated with the primary antibodies against eNOS $(1: 1000)$ and $\beta$-actin (1:1000) overnight at $4^{\circ} \mathrm{C}$. The PVDF membrane was washed 3 times with phosphate-buffered saline containing 0.05\% Tween-20 (PBST) and incubated with the horseradish peroxidase (HRP)-conjugated secondary antibody ( $1: 10000$ dilution) at $37^{\circ} \mathrm{C}$ for $1 \mathrm{~h}$. The PVDF membranes were washed 3 times with PBST again and labeled with the enhanced Pierce ${ }^{\mathrm{TM}}$ Fast Western blot Kit (Thermo Scientific Pierce) for $1 \mathrm{~min}$ at room temperature in dark. Finally, the PVDF membranes were exposed to the imaging system (ImageJ software, National Institutes of Health, Bethesda, MD, USA) to capture the light signals of protein bands. The eNOS protein level was expressed as a relative value to that of $\beta$-actin.

\section{Statistical analyses}

All experiments were performed at least in triplicate. For the 96-well microtiter tissue culture plates, 4 replicate wells were used per category. The data were analyzed by SPSS statistics software (version 15.0, SPSS Inc, Chicago, IL, USA). For significant differences between control and experimental values, the $p$ value between groups was determined by one-way analysis of variance followed by Tukey's test. The significance level was set at $p<0.05$.

\section{Results}

Cell viability and nitric oxide production was measured over a time course to determine the optimal experimental exposure time. The data in Fig. 2A shows that cell viability increased significantly $(p<0.05)$ after treatment with 1 , 20,40 , and $60 \mu \mathrm{M}$ myricetin for $12 \mathrm{~h}$, but that nitric oxide production is similar compared with the untreated control (Fig. 2B). In contrast, there was a significant decrease in cell viability at 80 and $100 \mu \mathrm{M}$ myricetin concentrations $(p<$ $0.001)$ with a corresponding significant decrease in nitric oxide production at $12 \mathrm{~h}(p<0.001)$ (Fig. $2 \mathrm{~A}$ and B). After 24 -h incubation time with the same range of myricetin concentrations, cell viability and nitric oxide production were significantly increased $(p<0.05)$ compared with untreated cells as shown in Fig. 2A and B. As for the 12-h incubation, concentrations of 80 and $100 \mu \mathrm{M}$ myricetin caused a significant decrease in cell viability and nitric oxide production compared with untreated cells $(p<0.05)$. After 48 -h incubation significant decreases in cell viability $(p<0.05)$ and nitric oxide production $(p<0.001)$ were observed at 


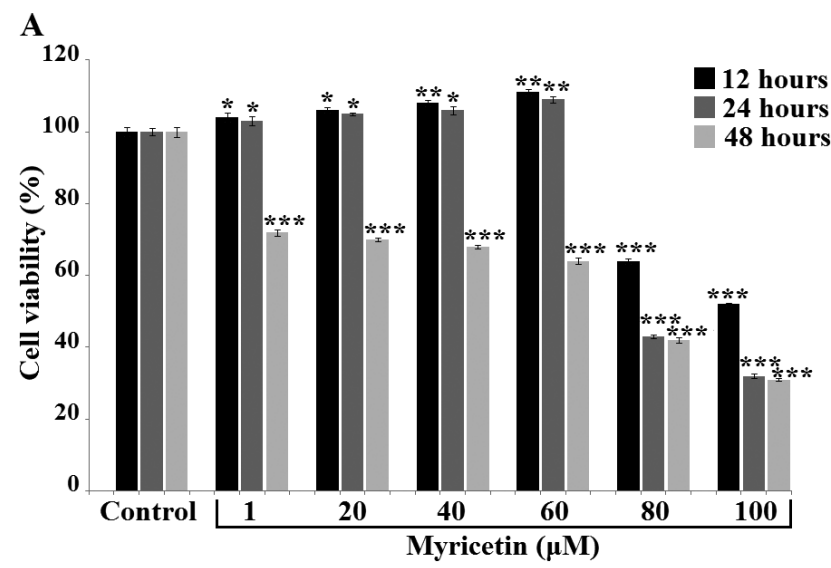

B

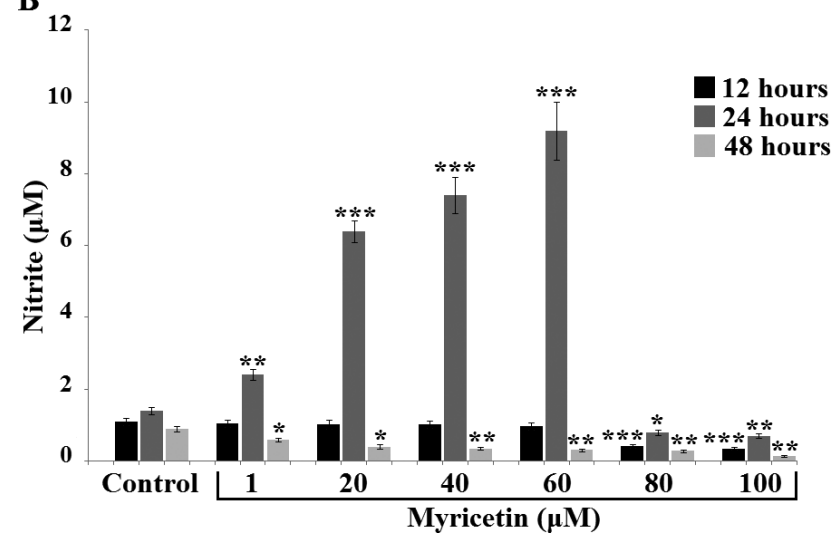

Figure 2. Effect of different concentrations of myricetin $(1-100 \mu \mathrm{M})$ on the cell viability (A) and nitric oxide production (B) of HUVEC. Data represented as mean \pm SD of three individual experiments. Comparisons of mean values were made using a one-way ANOVA followed by Tukey's test. ${ }^{*} p<0.05,{ }^{* *} p<0.001,{ }^{* * *} p<0.0001$ versus Control.

all myricetin concentrations $(1,20,40,60,80$ and $100 \mu \mathrm{M})$ (Fig. 2A and B). Based on the previous cell viability and nitric oxide production results, myricetin concentrations in the range 1-60 $\mu \mathrm{M}$ were selected for exposure to cells for $24 \mathrm{~h}$ in future experiments because higher myricetin concentrations $80-100 \mu \mathrm{M}$ produced a toxic effect on HUVEC cells (Fig. 2A and B).

In this study, incubation of HUVEC with different concentrations of myricetin $(1,20,40$ and $60 \mu \mathrm{M})$ for $24 \mathrm{~h}$ caused significant and dose-dependent inhibition of ACE activity compared with the control $(p<0.001)$ (Fig. 3).

ROS production in the HUVEC cell line, treated with different concentrations of myricetin for $24 \mathrm{~h}$, in the absence of angiotensin II stimulation, was not significantly different to ROS production in cells not treated with myricetin $(p>0.05)$ (Fig. 4). The ability of different concentrations of myricetin added to HUVEC cells for $24 \mathrm{~h}$ to reduce ROS production was assessed by flow cytometer analysis after treating cells with $10 \mathrm{nM}$ angiotensin II for $1 \mathrm{~h}$. The cells treated with angiotensin II showed a significant decrease in fluorescence intensity as the concentration of myricetin increased compared with cells treated with angiotensin II alone as a positive control $(p<0.001)$ (Fig. 4$)$.

Different concentrations of myricetin $(1,20,40$ and $60 \mu \mathrm{M})$ exposed to HUVEC cell line for $24 \mathrm{~h}$ caused a significant dose-dependent increase in intracellular $\mathrm{Ca}^{2+}$ concentration $(p<0.001)$ (Fig. 5).

The effects of myricetin at different concentrations (1, 20,40 , and $60 \mu \mathrm{M}$ ) on activation of the eNOS enzyme were detemlined in HUVEC cells after a $24 \mathrm{~h}$ exposure time. As shown in Fig. 6, myricetin caused a significant increase in eNOS enzyme activity that was dose-dependent $(p<0.05)$.
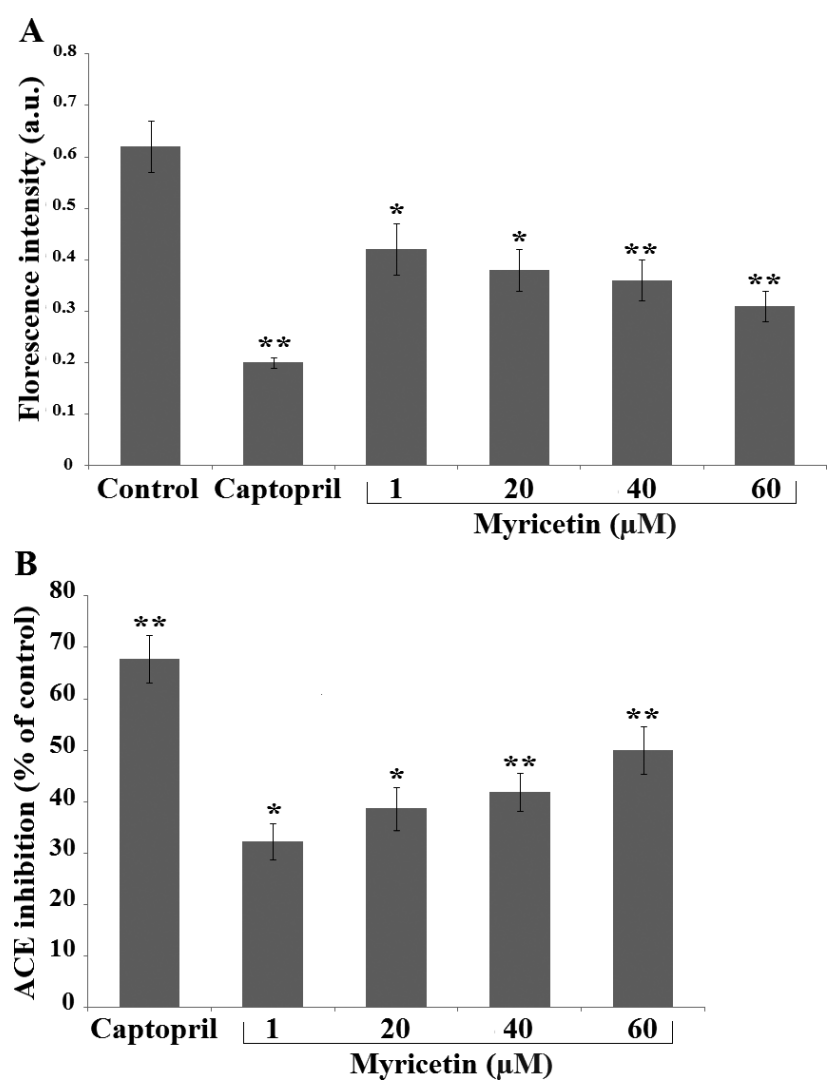

Figure 3. ACE activity in HUVEC exposed to myricetin $(1-60 \mu \mathrm{M})$ for $24 \mathrm{~h}$. A. Florescence intensity of negative control (untreated cell), positive control ( $1 \mu \mathrm{M}$ captopril) and cells treated with different myricetin concentrations. The fluorescent intensity is proportional to enzyme activity. B. ACE inhibition activity for positive control and treated cells with different myricetin concentrations in relative to negative control (untreated cell). Data represented as mean \pm SD of three individual experiments. Comparisons of mean values were made using a one-way ANOVA followed by Tukey's test, ${ }^{*} p<0.05,{ }^{*} p<0.001$ versus Control. ACE, angiotensin converting enzyme. 


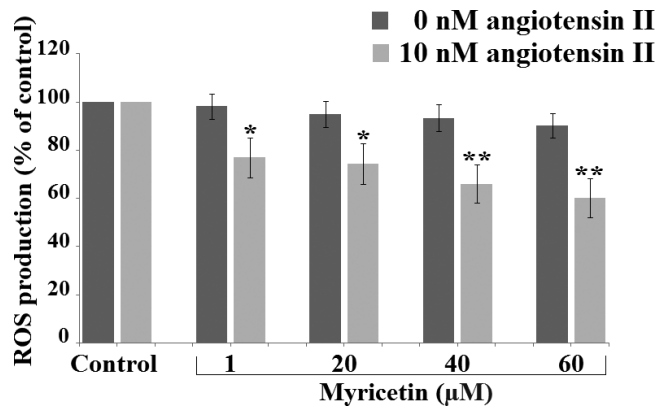

Figure 4. ROS production in HUVEC treated with different myricetin concentrations $(1-60 \mu \mathrm{M})$ with/without $10 \mathrm{nM}$ angiotensin II pretreatment for $1 \mathrm{~h}$. ROS production in the control group was considered as $100 \%$ and relative ROS production percentages of the other groups were expressed according to the control group. Data represented as mean \pm SD of three individual experiments. Comparisons of mean values were made using a one-way ANOVA followed by Tukey's test. ${ }^{\star} p<0.05,{ }^{* *} p<0.001$ versus Control. ROS, reactive oxygen species.

Western blot analysis using a specific antibody against eNOS revealed no change in eNOS protein expression in HUVEC cells treated with myricetin compared with untreated control cells (Fig. 7). The calcium concentration for $1 \mathrm{mM}$ EGTA was significantly decreased $(p<0.05)$; therefore, eNOS protein expression level was down regulated and eNOS enzyme activity decreased.

\section{Discussion}

Major research indicates that polyphenols have the ability to reduce the risk of cardiac disease such as atherosclerosis as well as hypertension (Persson et al. 2006). A wide concentration range of myricetin $(1-100 \mu \mathrm{M})$ was examined using an exposure time of $24 \mathrm{~h}$ on HUVEC cells. At concentrations of 1-60 $\mu \mathrm{M}$, no cytotoxicity was observed, while nitric oxide production increased dose-dependently. In contrast, at 80 and $100 \mu \mathrm{M}$ myricetin, a reduction in cell viability and consequently reduction in nitric oxide was observed, indicating toxicity at high levels of myricetin on HUVEC cells. The results of several studies investigating the effect of polyphenol to increase the bioavailability of nitric oxide were consistent with our findings. EA.hy296 cell line incubated with different concentrations of red wine polyphenol extract $(100-600 \mu \mathrm{g} / \mathrm{ml})$ for $18 \mathrm{~h}$ produced a significant increase in nitric oxide level (Leikert et al. 2002). Ugusman et al. (2014) showed that rutin administration at concentrations of $300 \mu \mathrm{M}$ significantly increased the level of nitric oxide after being added to HUVEC cells for $24 \mathrm{~h}$. Nitric oxide level was also significantly increased in a dose-dependent manner after incubating the HUVEC cell line for $8 \mathrm{~h}$ with quercetin (Jones et al. 2016).
To investigate whether myricetin has the potential to reduce hypertension via ACE inhibition, the activity of ACE was examined. This research showed significant inhibition of ACE activity associated with increasing myricetin dose. As a consequence of enzyme inhibition, levels of angiotensin II were decreased. Angiotensin II acts as a vasoconstrictor leading to increased blood pressure (Dos Santos et al. 2016), thus reduction of angiotensin II levels should decrease blood pressure. The mechanism of inhibition has been suggested by Persson et al. (2006) to involve polyphenol binding to $\mathrm{Zn}^{2+}$ ions in the active site of ACE. As reported by Selvaraj et al. (2013) myricetin has the ability to chelatemetal ions like $\mathrm{Fe}^{2+}$ and $\mathrm{Zn}^{2+}$. Numerous studies have been conducted on endothelial cell lines to examine the effect of polyphenols as ACE inhibitors (Parichatikanond et al. 2012). Hussain et al. (2018) evaluated the ACE inhibition potential of flavonoid fraction obtained from Coriandrum
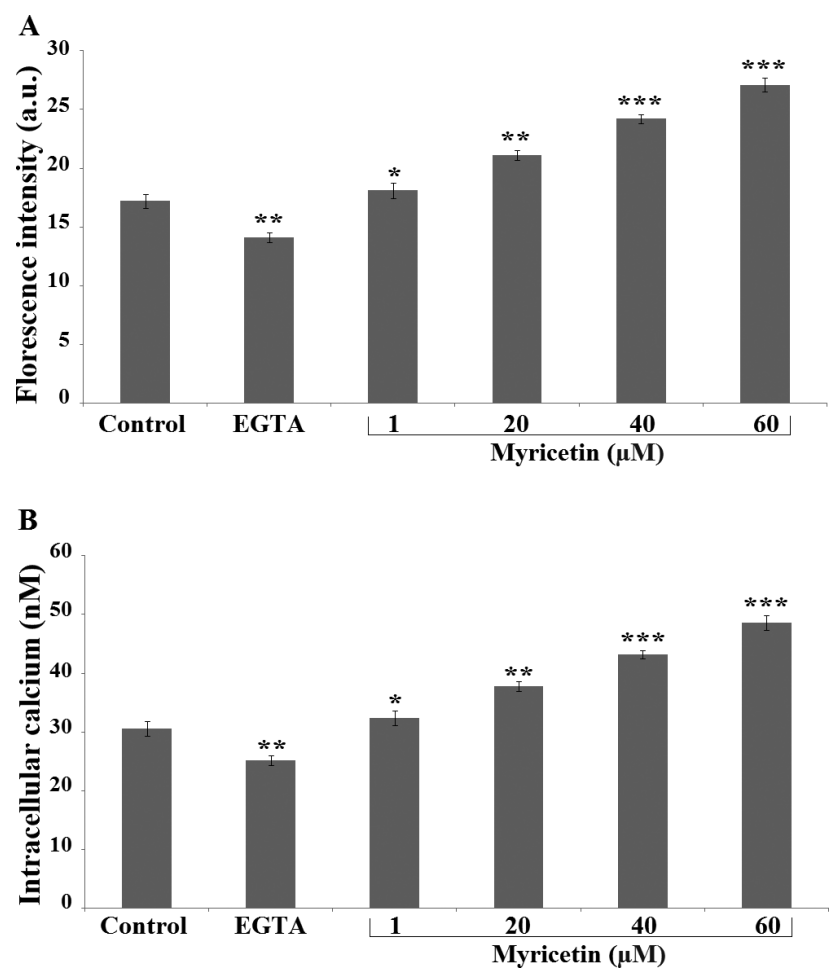

Figure 5. Intracellular calcium concentration in HUVEC exposed to myricetin $(1-60 \mu \mathrm{M})$ for $24 \mathrm{~h}$. A. Florescence intensity for control (untreated cell), negative control (1 mM EGTA) and cells treated with different myricetin concentrations. B. The intracellular calcium concentrations for control (untreated cell), negative control (1 mMEGTA) and cells treated with different myricetin concentrations. The fluorescent intensity is proportional to intracellular calcium concentrations. EGTA ( $1 \mathrm{mM}$ ) incubated for $3 \mathrm{~h}$ was used as a negative control. Data represented as mean $\pm \mathrm{SD}$ of three individual experiments. Comparisons of mean values were made using a one-way ANOVA followed by Tukey's test. ${ }^{*} p<0.05,{ }^{* *} p<0.001,{ }^{* * *} p<0.0001$ versus Control. 


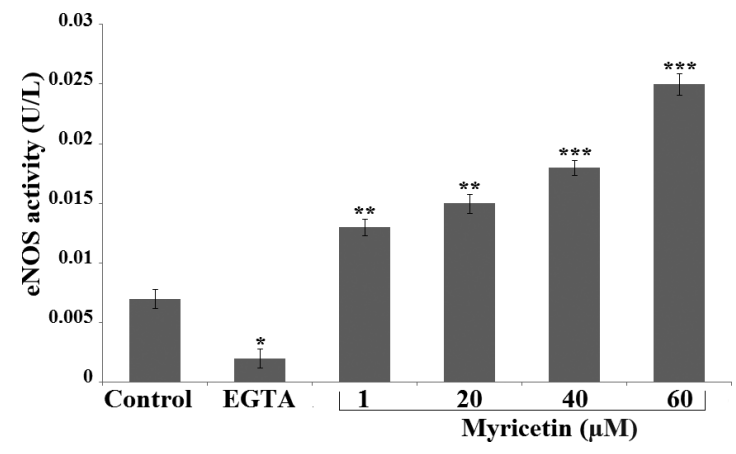

Figure 6. eNOS activity in HUVEC exposed to myricetin (1-60 $\mu \mathrm{M})$ for $24 \mathrm{~h}$. EGTA ( $1 \mathrm{mM}$ ) incubated for $3 \mathrm{~h}$ was used as a negative control. Data represented as mean \pm SD of three individual experiments. Comparisons of mean values were made using a one-way ANOVA followed by Tukey's test. ${ }^{\star} p<0.05,{ }^{* *} p<0.001,{ }^{* * *} p<$ 0.0001 versus Control. eNOS, endothelial nitric oxide synthase.

sativum. According to their results, ACE inhibition rate of the flavonoid fraction was $81.4 \%$. Pinocembrin, apigenin, pseudobaptigenin, galangin-5-methyl ether, quercetin, baicalein trimethyl ether, kaempferol dimethyl ether, pinobanksin-5-methylether-3-O-acetate, pinobanksin3-O-pentenoate, pinobanksin-3-O-phenylpropionate, pinobanksin-3-O-pentanoate, apigenin-7-O-glucuronoide, quercetin-3-O-glucoside, apigenin-3-O-rutinoside, rutin, isorhamnetin-3-O-rutinoside, quercetin dimethyl ether-3-O-rutinoside, daidzein, luteolin, pectolinarigenin, apigenin-C-glucoside, kaempferol-3-7-dimethyl ether-3-Oglucoside, and apigenin-7-O-(6-methyl-beta-D-glucoside) were identified from the flavonoid fraction obtained from C. sativum. Guerrero et al. (2012) reported that the $\mathrm{IC}_{50}$ values of luteolin, quercetin, rutin, kaempferol, rhoifolin and apigenin were $23,43,64,178,183$ and $196 \mu \mathrm{M}$, respectively. Epicatechin, epigallocatechin, epicatechin gallate and epigallocatechin gallate inhibited the activity of ACE in HUVEC cell line at all studied concentrations (Persson et al. 2006). In another study was performed on HUVEC cell line to investigate the inhibition of ACE enzyme after exposure to aqueous phenolic extract from Vaccinium myrtillus. The Vaccinium myrtillus extract contained several polyphenols such as quercetin, stillbene, resveratrol, ferulic acid and coumaric acid; these components significantly inhibited ACE activity in a dose dependent manner in HUVEC cell line treated for 10 min (Persson et al. 2009).

Angiotensin II has the ability to stimulate ROS production in endothelial cells through activation of a redox-sensitive signaling system. In an endothelial cell line, NADPH oxidase was considered as a source of ROS, responding to angiotensin II with the donation of an electron to reduce a molecule of oxygen to produce the superoxide anion, $\mathrm{O}_{2}{ }^{-}$(Förstermann et al. 2017). In our study, ROS production in the HUVEC cell line, treated with different concentrations of myricetin for $24 \mathrm{~h}$, in the absence of angiotensin II stimulation, was not significantly different to ROS production in cells not treated with myricetin. On the other hand, the superoxide production that was induced after incubation of cells with angiotensin II was significantly inhibited at all concentrations of myricetin. These results illustrate that myricetin has the ability to scavenge ROS and thereby protect cellular macromolecules from ROS-mediated damage. As reported previously from several in vitro studies, the presence of the hydroxyl group in phenolic compounds plays an important role in scavenging ROS (Bao and Lou 2006). Inhibition of superoxide levels was expected due to the presence of several hydroxyl groups within the chemical structure of myricetin (Semwal et al. 2016).

Myricetin, at studied doses, showed a significant increase in eNOS enzyme activity but there was no increase in the protein expression level of the eNOS enzyme. Myricetin may have increased the eNOS activity via eNOS phosphorylation which enhances activity via the activation of the redox-sensitive phosphatidylinositol-3 (PI3)/protein kinase B (AKT) pathways (Krga et al. 2018). Protein expression of eNOS enzyme in bovine aorteic cell line was not affected after incubation for $12 \mathrm{~h}$ with $50 \mu \mathrm{M}$ of punicalagin (Chen et al. 2008). In contrast, Leikert et al. (2002) found that red wine polyphenols water extract had increased eNOS protein levels after incubation in EA.hy926 cell line for 20 h. Ugusman et al. (2014) found a significant increase in protein expression and

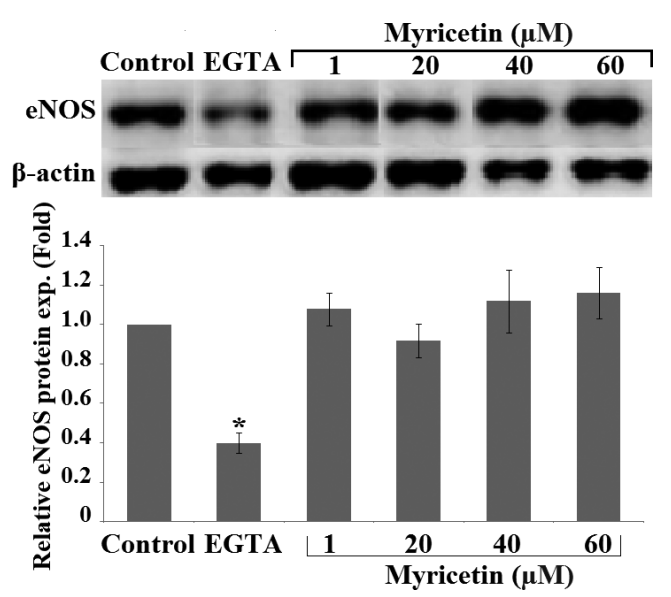

Figure 7. eNOS protein expression in HUVEC exposed to myricetin $(1-60 \mu \mathrm{M})$ for $24 \mathrm{~h}$. EGTA $(1 \mathrm{mM})$ incubated for $3 \mathrm{~h}$ was used as a negative control. eNOS protein expression in the control group was considered as 1.00 and relative eNOS protein expressions of the other groups were expressed according to the control group. Data represented as mean \pm SD of three individual experiments. Comparisons of mean values were made using a one-way ANOVA followed by Tukey's test. ${ }^{*} p<0.05$ versus Control. eNOS, endothelial nitric oxide synthase. 
activity of eNOS enzyme in HUVEC cell line after incubation with rutin at different concentrations for $24 \mathrm{~h}$. As seen in other research on polyphenols, the increase in nitric oxide can be mediated by increased activity and protein expression of the eNOS enzyme (Chen et al. 2008) or by scavenging of ROS that would normally degrade it (Krga et al. 2018).

eNOS enzyme activity is calcium-dependent (Leikert et al. 2002), therefore, the calcium concentration in HUVEC cells treated with myricetin was measured. This study demonstrates that myricetin produced a significant increase in calcium concentration in HUVEC cell line after incubation for $24 \mathrm{~h}$. Polyphenols can affect intracellular $\mathrm{Ca}^{2+}$ levels by releasing ions from intracellular stores or by increasing the entrance of $\mathrm{Ca}^{2+}$ through the cell membrane (Oak et al. 2018). One or both of these mechanisms may help to explain the significant increase of $\mathrm{Ca}^{2+}$ concentration caused by myricetin in the endothelial cell line. According to literature, red wine polyphenols showed a significant increase in calcium concentration in EA.hy926 cell line, which increased the eNOS protein level and showed a significant release of nitric oxide (Leikert et al. 2002). Bi et al. (2016) found a significant increase in intracellular calcium concentration in HUVEC cell line after incubation with naringin at different concentrations for $6 \mathrm{~h}$. As we have seen previous research results on polyphenols as calcium inducer were similar to our findings.

In conclusion, myricetin is a type of polyphenol that could play a role in reducing the risk of cardiovascular disease. As observed previously, myricetin incubated with HUVEC cells at different concentrations for $24 \mathrm{~h}$ produced a significant inhibition of ACE enzyme activity and increased nitric oxide production. Increased nitric oxide production was via increased eNOS activity due to an increase in calcium concentration. There was no induction of eNOS enzyme expression observed. This nitric oxide level is protected from destruction by ROS through myricetin scavenging activity. Our findings indicate that myricetin may be helpful for lowering blood pressure; this could be achieved through dietary intervention or by the production of new antihypertensive treatments from a natural product.

Acknowledgements. This research was financially supported by the Office of Scientific Research Projects of Van Yuzuncu Yil University under Grant number (TAP-2019-8120).

Conflict of interest. No conflict of interest was declared by the authors.

\section{References}

Balasuriya BWN, Rupasinghe HPV (2011): Plant flavonoids as angiotensin converting enzyme inhibitors in regulation of hypertension. F.F.H.D. 1, 172-188 https://doi.org/10.31989/ffhd.v1i5.132

Bao M, Lou Y (2006): Flavonoids from seabuckthorn protect endothelial cells (EA.hy926) from oxidized low-density lipoprotein induced injuries via regulation of LOX-1 and eNOS expression. J. Cardiovasc. Pharmacol. 48, 834-841 https://doi.org/10.1097/01.fjc.0000232064.64837.67

Bernstein KE, Khan Z, Giani JF, Cao DY, Bernstein EA, Shen XZ (2018): Angiotensin-converting enzyme in innate and adaptive immunity. Nat. Rev. Nephrol. 14, 325-336 https://doi.org/10.1038/nrneph.2018.15

Bi C, Jiang Y, Fu T, Hao Y, Zhu X, Lu Y (2016): Naringin inhibits lipopolysaccharide-induced damage in human umbilical vein endothelial cells via attenuation of inflammation, apoptosis and MAPK pathways. Cytotechnology 68, 1473-1487 https://doi.org/10.1007/s10616-015-9908-3

Bolisetty S, Jaimes EA (2013): Mitochondria and reactive oxygen species: physiology and pathophysiology. Int. J. Mol. Sci. 14, 6306-6344 https://doi.org/10.3390/ijms14036306

Braun LA, Rosenfeldt F (2013): Pharmaco-nutrient interactions - a systematic review of zinc and antihypertensive therapy. Int. J. Clin. Pract. 67, 717-725 https://doi.org/10.1111/ijcp.12040

Bredt DS, Snyder SH (1994): Nitric oxide: a physiologic messenger molecule. Annu. Rev. Biochem. 63, 175-195 https://doi.org/10.1146/annurev.bi.63.070194.001135

Burtenshaw D, Hakimjavadi R, Redmond EM, Cahill PA (2017): Nox, Reactive oxygen species and regulation of vascular cell fate. Antioxidants (Basel) 6, 90 https://doi.org/10.3390/antiox6040090

Cervantes-Gracia K, Llanas-Cornejo D, Husi H (2017): CVD and oxidative stress. J. Clin. Med. 6, 22 https://doi.org/10.3390/jcm6020022

Chen LG, Liu YC, Hsieh CW, Liao BC, Wung BS (2008): Tannin 1-alpha-O-galloylpunicalagin induces the calcium-dependent activation of endothelial nitric-oxide synthase via the phosphatidylinositol 3-kinase/Akt pathway in endothelial cells. Mol. Nutr. Food Res. 52, 1162-1171 https://doi.org/10.1002/mnfr.200700335

Do MH, Kim SN, Seo SY, Yeo EJ, Kim SY (2015): $\delta$-Tocopherol prevents methylglyoxal-induced apoptosis by reducing ROS generation and inhibiting apoptotic signaling cascades in human umbilical vein endothelial cells. Food Funct. 6, 1568-1577 https://doi.org/10.1039/C4FO01110D

Dong Y, Xu W, Liu C, Liu P, Li P, Wang K (2019): Reactive oxygen species related noncoding rnas as regulators of cardiovascular diseases. Int. J. Biol. Sci. 15, 680-687 https://doi.org/10.7150/ijbs.30464

Dos Santos RL, Dellacqua LO, Delgado NT, Rouver WN, Podratz PL, Lima LC, Piccin MP, Meyrelles SS, Mauad H, Graceli JB, Moyses MR (2016): Pomegranate peel extract attenuates oxidative stress by decreasing coronary angiotensin-converting enzyme (ACE) activity in hypertensive female rats. J. Toxicol. Environ. Health A 79, 998-1007 https://doi.org/10.1080/15287394.2016.1213690

Förstermann U, Xia N, Li H (2017): Roles of vascular oxidative stress and nitric oxide in the pathogenesis of atherosclerosis. Circ. Res. 120, 713-735 
https://doi.org/10.1161/CIRCRESAHA.116.309326

Fuchs S, Xiao HD, Hubert C, Michaud A, Campbell DJ, Adams JW, Capecchi MR, Corvol P, Bernstein KE (2008): Angiotensinconverting enzyme C-terminal catalytic domain is the main site of angiotensin I cleavage in vivo. Hypertension 51, 267-274 https://doi.org/10.1161/HYPERTENSIONAHA.107.097865

Gowrisankar YV, Clark MA (2016): Angiotensin II regulation of angiotensin-converting enzymes in spontaneously hypertensive rat primary astrocyte cultures. J. Neurochem. 138, 74-85 https://doi.org/10.1111/jnc.13641

Grynkiewicz G, Poenie M, Tsien RY (1985): A new generation of $\mathrm{Ca} 2+$ indicators with greatly improved fluorescence properties. J. Biol. Chem. 260, 3440-3450

Guerrero L, Castillo J, Quiñones M, Garcia-Vallvé S, Arola L, Pujadas G, Muguerza B (2012): Inhibition of angiotensin-converting enzyme activity by flavonoids: structure-activity relationship studies. PLoS One 7, e49493 https://doi.org/10.1371/journal.pone.0049493

Hussain F, Jahan N, Rahman KU, Sultana B, Jamil S (2018): Identification of hypotensive biofunctional compounds of Coriandrum sativum and evaluation of their angiotensin-converting enzyme (ACE) inhibition potential. Oxid. Med. Cell Longev. 2018, 4643736 https://doi.org/10.1155/2018/4643736

Jones HS, Gordon A, Magwenzi SG, Naseem K, Atkin SL, Courts FL (2016): The dietary flavonol quercetin ameliorates angiotensin II-induced redox signaling imbalance in a human umbilical vein endothelial cell model of endothelial dysfunction via ablation of p47phox expression. Mol. Nutr. Food Res. 60, 787-797 https://doi.org/10.1002/mnfr.201500751

Kapiloff MS, Strittmatter SM, Fricker LD, Snyder SH (1984): A fluorometric assay for angiotensin-converting enzyme activity. Anal. Biochem. 140, 293-302 https://doi.org/10.1016/0003-2697(84)90167-2

Khaddaj Mallat R, Mathew John C, Kendrick DJ, Braun AP (2017): The vascular endothelium: A regulator of arterial tone and interface for the immune system. Crit. Rev. Clin. Lab. Sci. 54, 458-470 https://doi.org/10.1080/10408363.2017.1394267

Krga I, Tamaian R, Mercier S, Boby C, Monfoulet LE, Glibetic M, Morand C, Milenkovic D (2018): Anthocyanins and their gut metabolites attenuate monocyte adhesion and transendothelial migration through nutrigenomic mechanisms regulating endothelial cell permeability. Free Radic. Biol. Med. 124, 364-379 https://doi.org/10.1016/j.freeradbiomed.2018.06.027

Lee da H, Lee CS (2016): Flavonoid myricetin inhibits TNF- $\alpha-$ stimulated production of inflammatory mediators by suppressing the Akt, mTOR and NF- $\mathrm{BB}$ pathways in human keratinocytes. Eur. J. Pharmacol. 784, 164-172 https://doi.org/10.1016/j.ejphar.2016.05.025

Leikert JF, Räthel TR, Wohlfart P, Cheynier V, Vollmar AM, Dirsch VM (2002): Red wine polyphenols enhance endothelial nitric oxide synthase expression and subsequent nitric oxide release from endothelial cells. Circulation 106, 1614-1617 https://doi.org/10.1161/01.CIR.0000034445.31543.43

Li XC, Zhang J, Zhuo JL (2017): The vasoprotective axes of the renin-angiotensin system: Physiological relevance and thera- peutic implications in cardiovascular, hypertensive and kidney diseases. Pharmacol. Res. 125, 21-38 https://doi.org/10.1016/j.phrs.2017.06.005

Loizzo MR, Said A, Tundis R, Rashed K, Statti GA, Hufner A, Menichini $F$ (2007): Inhibition of angiotensin converting enzyme (ACE) by flavonoids isolated from Ailanthus excelsa (Roxb) (Simaroubaceae). Phytother. Res. 21, 32-36 https://doi.org/10.1002/ptr.2008

Maiuolo J, Gliozzi M, Musolino V, Carresi C, Nucera S, Macrì R, Scicchitano M, Bosco F, Scarano F, Ruga S, et al. (2019): The role of endothelial dysfunction in peripheral blood nerve barrier: Molecular mechanisms and pathophysiological implications. Int. J. Mol. Sci. 20, 1-20 https://doi.org/10.3390/ijms20123022

Mittal BV, Singh AK (2010): Hypertension in the developing world: challenges and opportunities. Am. J. Kidney Dis. 55, 590-598 https://doi.org/10.1053/j.ajkd.2009.06.044

Mosmann T (1983): Rapid colorimetric assay for cellular growth and survival: application to proliferation and cytotoxicity assays. J. Immunol. Methods 65, 55-63 https://doi.org/10.1016/0022-1759(83)90303-4

Nanayakkara GK, Wang H, Yang X (2019): Proton leak regulates mitochondrial reactive oxygen species generation in endothelial cell activation and inflammation - A novel concept. Arch. Biochem. Biophys. 662, 68-74 https://doi.org/10.1016/j.abb.2018.12.002

Oak MH, Auger C, Belcastro E, Park SH, Lee HH, Schini-Kerth VB (2018): Potential mechanisms underlying cardiovascular protection by polyphenols: Role of the endothelium. Free Radic. Biol. Med. 122, 161-170 https://doi.org/10.1016/j.freeradbiomed.2018.03.018

Osseni RA, Debbasch C, Christen MO, Rat P, Warnet JM (1999): Tacrine-induced reactive oxygen species in a human liver cell line: The role of anethole dithiolethione as a scavenger. Toxicol. In Vitro 13, 683-688 https://doi.org/10.1016/S0887-2333(99)00050-8

Parichatikanond W, Pinthong D, Mangmool S (2012): Blockade of the renin-angiotensin system with delphinidin, cyanin, and quercetin. Planta Med. 78, 1626-1632 https://doi.org/10.1055/s-0032-1315198

Persson IA, Josefsson M, Persson K, Andersson RG (2006): Tea flavanols inhibit angiotensin-converting enzyme activity and increase nitric oxide production in human endothelial cells. J. Pharm. Pharmacol. 58, 1139-1144 https://doi.org/10.1211/jpp.58.8.0016

Persson IA, Persson K, Andersson RG (2009): Effect of Vaccinium myrtillus and its polyphenols on angiotensin-converting enzyme activity in human endothelial cells. J. Agric. Food Chem. 57, 4626-4629 https://doi.org/10.1021/jf900128s

Selvaraj S, Krishnaswamy S, Devashya V, Sethuraman S, Krishnan UM (2013): Flavonoid-metal ion complexes: a novel class of therapeutic agents. Med. Res. Rev. 34, 677-702 https://doi.org/10.1002/med.21301

Semwal DK, Semwal RB, Combrinck S, Viljoen A (2016): Myricetin: A dietary molecule with diverse biological activities. Nutrients 8, 90 
https://doi.org/10.3390/nu8020090

Shu X, Keller TC 4th, Begandt D, Butcher JT, Biwer L, Keller AS, Columbus L, Isakson BE (2015): Endothelial nitric oxide synthase in the microcirculation. Cell. Mol. Life Sci. 72, 4561-4575

https://doi.org/10.1007/s00018-015-2021-0

Ugusman A, Zakaria Z, Chua KH, Nordin NA, Abdullah Mahdy Z (2014): Role of rutin on nitric oxide synthesis in human umbilical vein endothelial cells. ScientificWorldJournal 2014, 169370

https://doi.org/10.1155/2014/169370
Wang X, Wu S, Xu D, Xie D, Guo H (2011): Inhibitor and substrate binding by angiotensin-converting enzyme: quantum mechanical/molecular mechanical molecular dynamics studies. J. Chem. Inf. Model. 51, 1074-1082 https://doi.org/10.1021/ci200083f

Yao Y, Lin G, Xie Y, Ma P, Li G, Meng Q, Wu T (2014): Preformulation studies of myricetin: a natural antioxidant flavonoid. Pharmazie 69, 19-26

Received: July 10, 2019

Final version accepted: February 11, 2020 